\title{
Comparative Performance of Conservation Machinery System for Rice-Chickpea Cropping System in Vertisol of Chhattisgarh
}

\author{
Jitendra Kumar*, A.K. Dave and Shambhu Singh
}

Department of Farm Machinery and Power Engineering, IGKV, Raipur (C.G.), India

*Corresponding author

\section{A B S T R A C T}

\begin{tabular}{l} 
Ke y w o r d s \\
Rice (Oryza sativa \\
$\begin{array}{l}\text { L.) and chickpea } \\
\text { (Cicer arietinum), } \\
\text { Cropping System }\end{array}$ \\
\hline Article Info \\
\hline $\begin{array}{l}\text { Accepted: } \\
\text { 12 December } 2020 \\
\text { Available Online: } \\
\text { 10 January } 2021\end{array}$ \\
\hline
\end{tabular}

Rice (Oryza sativa L.) and chickpea (Cicer arietinum L) is the most extensively cultivated cereal-pulses crops in India and other countries. In this experiment, for comparative performance of conservation machinery system in rice -chickpea cropping system various farm machines were used viz ridge and furrow planter sowing (T1), conventional seed cum fertilizer drill sowing (T2), zero till drill sowing (T3) and happy seeder sowing (T4). In T1 treatment fuel consumption was measured higher as compared to other treatments because there are used more tillage operation for better ridge and furrow formation. T3 and T4 were higher conservation of moisture content of the soil caused by incorporation of rice straw. Yiled attribute viz., Test weight was measured higher 28.28, seed yield was measured higher 18.25, harvest index 34.22 was measured higher in T1 (ridge and furrow sowing) treatment. The total energy input required in T1, T2, T3 and T4 treatments are 9221.5, 7842, 5448.5 and 5520 MJ ha ${ }^{-1}$, respectively. Minimum energy input requirement observed in T3 treatment because there is no tillage done followed by T4 (happy seeder sowing). In this experiment the total cost of cultivation (fixed and operating cost) required in T1, T2, T3 and T4 are 31261.36, 28107.07, 22734.25 and 23319.79 ₹ /ha, respectively. In terms of total energy, total cost and total time requirement for chickpea production zero tillage and happy seeder sowing was found less than conventional and ridge and furrow sowing therefore, zero tillage and happy seeder has been recommended for early sowing with minimization of cultivation cost and reducing input energy consumption during ricecropping system.

\section{Introduction}

Rice-chickpea cropping system is one of the important cropping systems being followed in Chhattisgarh as well as in India and occupies considerable geographical distribution. Rice (Oryza sativa) is occupies 158 Mha land throughout the world and it is a component of widely varying cropping systems. In our country, rice is cultivated under area of 43.95 million hectare with a production level of 104.80 million tonnes and a yield of approximately $2390 \mathrm{~kg} / \mathrm{ha}$ (Agricultural Statistics at a glance- 2015). The output of Indian rice grew from 53.6 million tonnes in 1980 to $110-115$ million tonnes in 2015-16. In India total chickpea was cultivated about 8.399 million hectare. The country harvested 
average production of 7.058 million tonnes at the productivity level of $840 \mathrm{~kg} \mathrm{ha}^{-1}$ during 2015-16. Chhattisgarh has contributed a significant 3.18 percent of the total chickpea production area and 3.13 per cent of total chickpea production in the country (Annual report DPD 2015-16).

Chickpea yield may be decreased by this soil condition (Boparai et al., 1992), probably by limiting root development and distribution. Plant residue is very necessary for the regeneration and maintenance of the soil structure under cropping system, however for different purposes, the amount of residue returned to the soil is not sufficient. Tillage is the mechanical manipulation of soil during plant growth to hold it lost for plant growth and clear of weeds (FAO, 1993). The fundamental aims of tillage are to prepare appropriate seed beds for plant growth, to kill competitive weeds and to improve the physical quality of the soil. Conservation tillage (CT) applies to cropping systems for decreased tillage including no-tillage, strip tillage, minimal till, mulch framing for stubble, mulch tillage and ridge tillage. At the same time, several studies have demonstrated that these systems can improve soil quality, reduce erosion and compaction, increase grain yield, soil organic matter and moderate soil temperatures. Different conservation machines for sowing of chickpea crop are happy seeder, inclined plate planter, ridge planter and zero till seed cum fertilizer drill. Keeping this in view, the investigation was undertaken to know the sustainability of chickpea cultivation after rice under different conservation operations. The rice-chickpea cropping system required different resources. For the best utilization of these resources we need to focus on their cultivation techniques. Cultivation must be performed within the 'friable range' of the soil type to avoid damaging the soil i.e. not during or after heavy rainfall, as this would result in compaction and soil smearing. This study has been planned to know the comparative performance of conservation machinery system for rice chickpea cropping system.

\section{Materials and Methods}

\section{Experimental site:}

The experiment was conducted in rabi season located at the Research Farm, Indira Gandhi Krishi Vishwavidyalaya, Raipur (Chhattisgarh) during 2016-17 and 2017-18, where adequate facilities available for experimentation. Raipur is situated in the central part of Chhattisgarh at Longitude $81.36^{\circ} \mathrm{E}$ and Latitude $21.16^{\circ} \mathrm{N}$ at an Altitude of 298.56 meters above the mean sea level, respectively on paddy crop residue on combine harvested paddy field.

\section{Design of experiment}

In the experiment, for evaluation of comparative performance of different conservation machinery system in rice chickpea cropping system the following treatment combination are selected for experiment.

In these experiment machine parameter viz.slip of tractor, effective field capacity, draft of sowing machines and fuel consumption, soil parameter viz. (moisture content and bulk density), yield attributes viz.(seed index, seed yield, harvest index), energy analysis and cost analysis was done.

\section{Machine parameter}

\section{Slip of tractor}

Tire slip occurs when the tires are turning faster than the ground speed of the tractor. Due to slip the power of a tractor engine develops is used to pull an implement through 
the soil. The conventional method of measuring tractor drive-wheel slip consists of measuring the base (unloaded) distance for a given number of drive wheel revolutions and then measuring the loaded distance for the same number of wheel revolutions.

Percent slip is given by the relation (Zoerb and Popoff, 1967):

Percent slip $(\%)=\frac{100-(B-L)}{B}$

Where, $\mathrm{B}=$ Base distance, $\mathrm{m}$; $\mathrm{L}=$ Loaded distance, $\mathrm{m}$.

\section{Effective field capacity}

Effective field capacity (EFC) of a farm machine is calculated by dividing the area ended or completed by the hour of actual time.

$\mathrm{EFC}=\frac{W S)}{10} x n$

Where, EFC = Effective field capacity of the machine, ha/h; $\mathrm{W}=$ Width of the machine, $\mathrm{m}$; $\mathrm{S}=$ Speed of the machine, $\mathrm{km} / \mathrm{h}$; and $\mathrm{n}=$ Efficiency of the machine, percentile.

\section{Fuel consumption}

For the measurement of fuel consumption $(\mathrm{l} / \mathrm{h})$ the intake and over flow fuel line was connected to a cylindrical container from bottom and top (shown in plate 3.21).The cylindrical container has the capacity of $3.0 \ell$ and having the marking in $50 \mathrm{ml}$ apart. In each treatment, the time of operation, area covered and the fuel consumed ( $\mathrm{ml})$ was observed and fuel consumption was estimated as given below:

Fuel consumption $(1 / \mathrm{ha})=$

$$
=\frac{\text { Fuel consumption }\left(\frac{\mathrm{ml}}{\mathrm{g}}\right)}{\text { Area covered }\left(\frac{\mathrm{m}^{2}}{\mathrm{~s}}\right)} \times 10
$$

\section{Draft of implements/machines}

The draft of the implement is calculated by two tractor method attached by a load cell with and without implement. The difference gives the draft of the implements. Pull force (P) is measured with help of hydraulic or gauge dynamometer and cone index, pull $\left({ }^{\theta}\right)$ with the horizontal. The horizontal component of pull is called draft.

Draft (D) is calculated as under $D=P \cos \theta \mathrm{kgf}$

\section{Moisture content of the soil}

Soil moisture content on dry weight basis was determined randomly after sowing, 30 DAS, 60 DAS and at the time of harvesting in different treatments. The soil samples were weighed using an electronic balance having least count of $0.001 \mathrm{~g}$. The $30 \mathrm{~g}$ soil samples were placed in a hot dry air oven at $105^{\circ} \mathrm{C}$ for 24 hours. The dried samples were weighed and difference in weight was recorded. The moisture percent (dry basis) was calculated using the relationship given below.

$\mathrm{Mc}(\mathrm{db}) \%=\frac{\mathrm{Ww}-W_{d}}{\mathrm{Wd}} \times 100$

Where, $\mathrm{mc}=$ Moisturecontent; $\mathrm{Ww}=$ Weight of undried soil $(\mathrm{g})$; and $\mathrm{Wd}=$ Weight of oven dried soil, (g).

\section{Soil Bulk density}

The bulk density was determined on dry weight basis randomly at the time of sowing and after 30, 60 days of sowing and at time of harvesting of all treatments at the depth as 0$150 \mathrm{~mm}$ using a core cutter. The samples for 
drying were placed in an oven at $105^{\circ} \mathrm{C}$ for 24 hours. The dried samples were re-weighed in an electrical balance and the difference was recorded. The bulk density of soil was determined by using following formula.

$\mathrm{BD}=\frac{\mathrm{M}}{\mathrm{V}}$

$\mathrm{BD}=$ Soil bulk density $\mathrm{g} / \mathrm{cc}$ );

$\mathrm{M}=$ Dry soil mass in the core cutter $(\mathrm{g})$;

$\mathrm{V}=$ Volume of cylindrical core cutter $\left(\mathrm{cm}^{3}\right)$;

\section{Crop parameter}

\section{Test weight}

The thousand seeds were randomly taken from the finally cleaned produce of each plot for recording test weight. Then weight of 1000 seeds of plot was recorded separately plot wise using electrical weighing machine.

\section{Seed yield}

The seed yield per net plot was recorded after weighing the seeds with the help of double pan balance. Finally, seed yield of each plot was converted in to seed yield per hectare by multiplying it with appropriate conversion factor.

Seed yield, $\mathrm{kg} / \mathrm{ha}=$

seed yield / treatment

Area/treatment $\quad \mathrm{x}$ area/ha

\section{Harvest index}

It was calculated for each treatment as per formula given below suggested by Nichiporvich (1967):-

\section{Energy and cost analysis}

Energy required for wheat crop was measured as source and operation wise in which inputoutput energy ratio and other energy calculation was measured for experiment (Jat et al., 2015). The operation cost was calculated in two way fixed cost and operation cast. In operation cast include Lubricants, fuel, Repair- maintenance and wages.

\section{Results and Discussion}

\section{Machine parameter}

\section{Slip of tractor}

Slip of tractor in, ridge and furrow planter, conventional seed cum fertilizer drill, zero till drill, happy seeder, cultivator and rotavator was observed $2.1,1.4,1.9,1.7,1.4$ and -1.3 respectively. Rotavator measured negative slip.

\section{Effective field capacity and draft of machine}

It was found that maximum field capacity was recorded in $\mathrm{T} 1$ followed by $\mathrm{T} 2$. Lowest draft was observed in the case of $\mathrm{T} 2$ followed by T3 due to better tilth condition in T2 treatment (cultator $\mathrm{x} 2+$ rotavator $\mathrm{x} 2$ ) and the no tillage operation performed in zero tillage treatment field respectively, which was given in Table 1.

\section{Fuel consumption}

Minimum fuel consumption for sowing operation was found in T3 treatment, zero till seed drill while maximum fuel consumption was obtained in T1 treatment (ridge and furrow sowing). (Table 1)

\section{Soil parameter}

Observing moisture content was higher in T4 treatment and lower in $\mathrm{T} 1$ treatment before 
second irrigation. (Fig 1) A different observation was done in the moisture content of soil for other irrigation. After at harvest stage the moisture content of soil was higher in T1 treatment and lower in T4 treatment. Observing soil bulk density was higher in T3 treatment and lower in T1 treatment with the all crop growth intervals. (Fig 2)

\section{Crop parameter}

Test weight was measured higher $28.28 \mathrm{~g}$, seed yield was measured higher $18.25 \mathrm{q} \mathrm{ha}^{-1}$, harvest index34.22 was measured higher in T1 treatment. However, Test weight was measured lowest $22.81 \mathrm{~g}$, seed yield was measured lowest $13.78 \mathrm{q} \mathrm{ha}^{-1}$, harvest index25.47 was measured lowest in T4 treatment. (Table 2)

\section{Energy and cost analysis}

In this experiment energy required in $\mathrm{T} 1, \mathrm{~T} 2$, T3 and T4 treatments are 9221.5, 7842, 5448.5 and $5520 \mathrm{MJ} \mathrm{ha}^{-1}$, respectively (Fig 3). Minimum energy requirement observed in T3 treatment because there is no tillage done followed by T4 (happy seeder sowing). In this experiment the total cost of cultivation (fixed and operating cost) required in $\mathrm{T} 1, \mathrm{~T} 2, \mathrm{~T} 3$ and T4 are 31261.36, 28107.07, 22734.25 and 23319.79 ₹/ha, respectively. In T3 treatment observed lower cost requirement because there is no tillage work done and labor work are minimum followed by T4 (happy seeder) treatment.

Table.1 Average sowing machine parameter

\begin{tabular}{|c|c|c|c|c|}
\hline Treatment & Slip (\%) & $\begin{array}{c}\text { Draft } \\
\mathbf{k N}\end{array}$ & $\begin{array}{c}\text { Effective field } \\
\text { capacity, ha } \mathbf{h}^{\mathbf{- 1}}\end{array}$ & $\begin{array}{c}\text { Fuel } \\
\text { consumption }_{\mathbf{1} \mathbf{h}^{-\mathbf{1}}}\end{array}$ \\
\hline $\mathbf{T}_{\mathbf{1}}$ & 2.4 & 3.48 & 0.47 & 4.2 \\
\hline $\mathbf{T}_{\mathbf{2}}$ & 1.4 & 2.6 & 0.45 & 3.7 \\
\hline $\mathbf{T}_{\mathbf{3}}$ & 1.9 & 2.8 & 0.42 & 3.1 \\
\hline $\mathbf{T}_{\mathbf{4}}$ & 1.7 & 3.0 & 0.39 & 3.5 \\
\hline
\end{tabular}

Table.2 Effect of different sowing methods of chickpea on seed index, seed yield and harvest index

\begin{tabular}{|l|c|c|c|c|c|c|c|c|c|}
\hline \multirow{2}{*}{ Treatment } & \multicolumn{3}{|c|}{ Seed Index, } & \multicolumn{3}{c|}{ Seed yield, q ha } & \multicolumn{3}{c|}{ Harvest index } \\
\cline { 2 - 11 } & $2016-17$ & $\begin{array}{c}2017- \\
18\end{array}$ & Mean & $\begin{array}{c}2016- \\
17\end{array}$ & $\begin{array}{c}2017- \\
18\end{array}$ & Mean & $\begin{array}{c}2016- \\
17\end{array}$ & $\begin{array}{c}2017- \\
18\end{array}$ & Mean \\
\hline Sowing method of chickpea \\
\hline $\mathbf{T}_{\mathbf{1}}$ & 28.57 & 28 & 28.28 & 19.2 & 17.3 & 18.25 & 35.43 & 33.01 & 34.22 \\
\hline $\mathbf{T}_{\mathbf{2}}$ & 27.57 & 25.9 & 26.73 & 17.7 & 16.17 & 16.93 & 30.26 & 28.65 & 29.45 \\
\hline $\mathbf{T}_{\mathbf{3}}$ & 24.53 & 24.57 & 24.55 & 14.8 & 13.77 & 14.28 & 26.76 & 25.24 & 26 \\
\hline $\mathbf{T}_{\mathbf{4}}$ & 23.93 & 21.7 & 22.81 & 14.47 & 13.1 & 13.78 & 26.81 & 24.13 & 25.47 \\
\hline $\mathbf{S E m} \pm$ & 0.49 & 0.22 & 0.35 & 0.82 & 0.12 & 0.47 & 1.16 & 0.52 & 0.84 \\
\hline $\mathbf{C D}(\mathbf{P}=\mathbf{0 . 0 5})$ & 2.97 & 1.33 & 2.15 & 5.02 & 0.74 & 2.88 & 7.04 & 3.17 & 5.10 \\
\hline
\end{tabular}



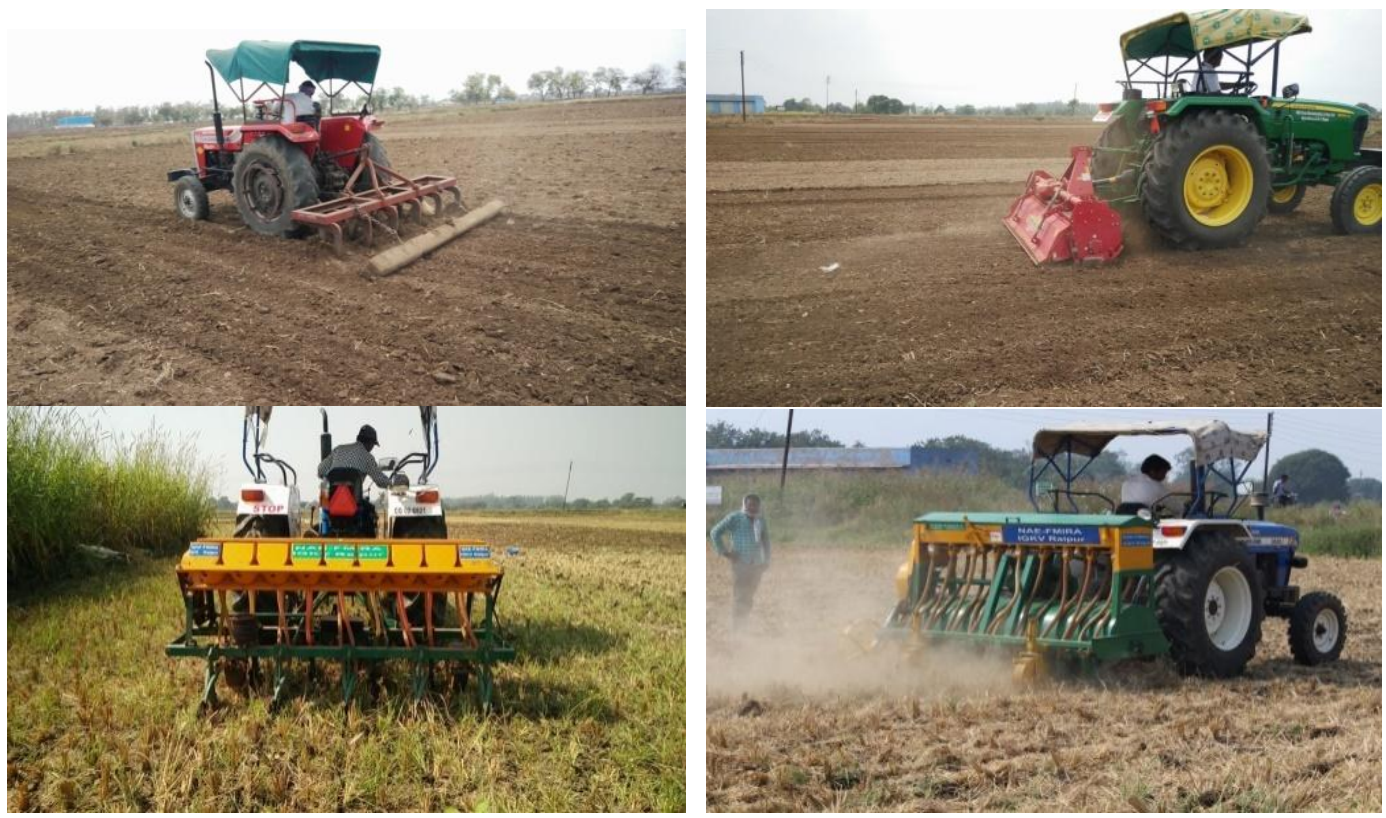

Fig.1 Soil moisture content in relation to different sowing methods of chickpea

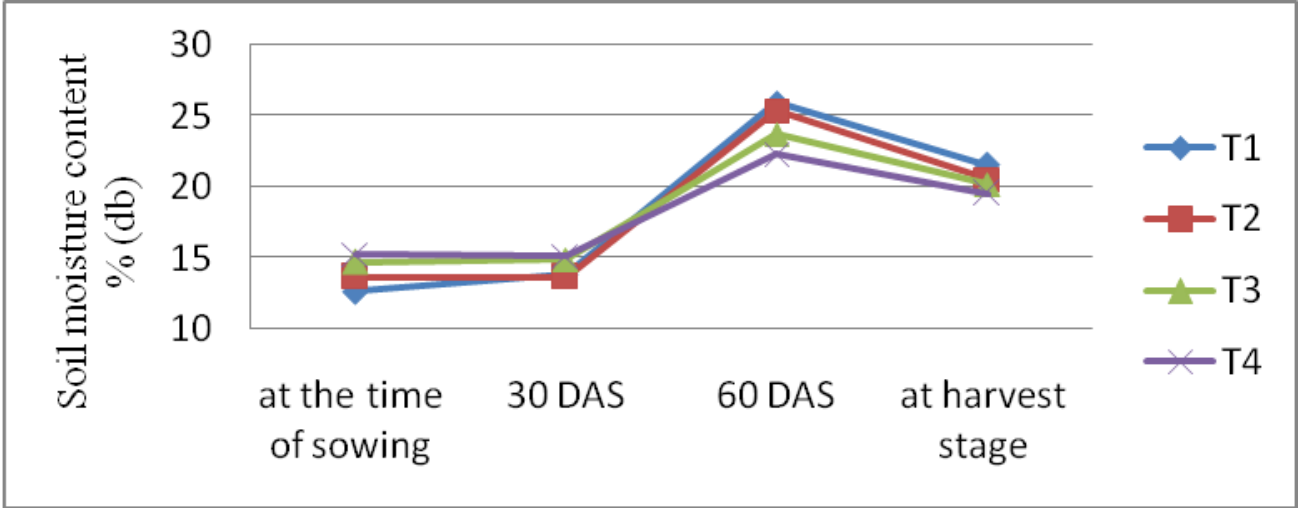

Fig.2 Soil bulk density in relation to different sowing methods of chickpea

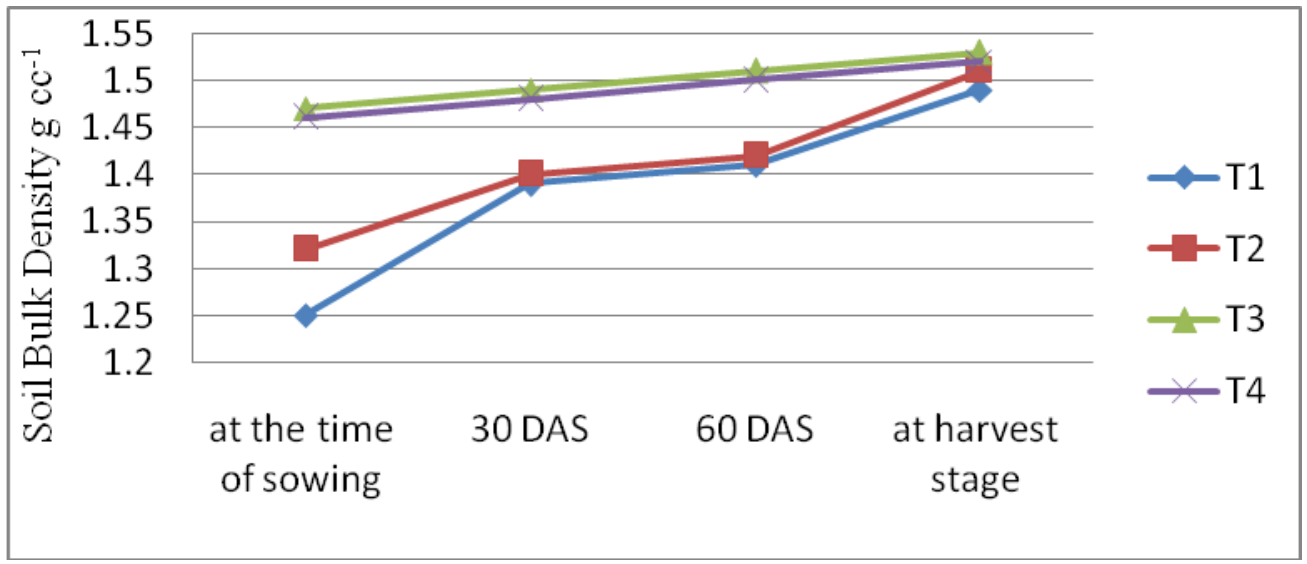


Fig.3 Mean energy parameters for different sowing methods of chickpea
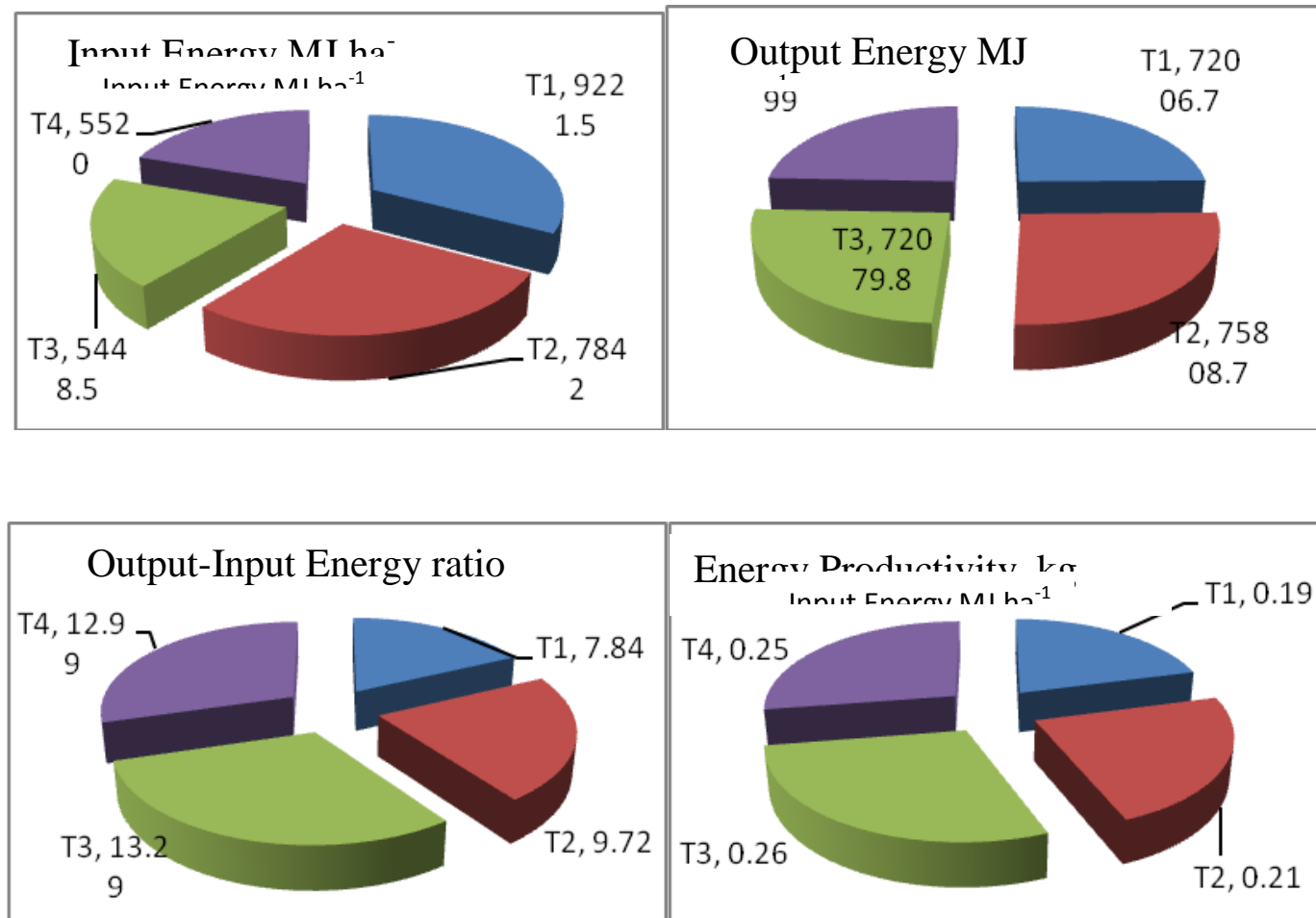

Based on results of two years investigation the following conclusion has been drawn-

Significantly minimum average time required per hectare for combined tillage and sowing operation in different sowing method of chickpea was recorded $2.3 \mathrm{~h}$ in treatment $\mathrm{T} 3$ (zero tillage sowing) during both the year and the maximum average time of 16.09 hours was obtained in treatment T4 (m.b. plough $\mathrm{x} 1$ + Cultivator $\times 2+$ Rotavator $\times 2+$ ridge and furrow sowing)

The results from input energy consumption concluded that the optimum seed bed preparation and sowing operations for the study ranged lowest was found 5448.5 MJ ha ${ }^{1}$ in treatment zero tillage sowing of chickpea (T3) there was a saving of about $74.76 \%$ in time requirement, $75.8 \%$ in fuel consumption and $75.05 \%$ in energy expenditure for tillage and sowing operations, comparing with (T1) ridge and furrow sowing.

The zero tillage and happy seeder sowing was found maximum in terms of $\mathrm{B}: \mathrm{C}$ ratio and minimum in terms of yield parameters and total cost of cultivation. However in terms of total energy, total cost and total time requirement for chickpea production zero tillage and happy seeder sowing was found less than conventional and ridge and furrow sowing therefore zero tillage and happy seeder has been recommended for early sowing with minimization of cultivation cost and reducing input energy consumption during rice- cropping system.

\section{References}

Boparai B.S., Yadvindersingh, Sharma, B.D. 1992. Effect of green manuring with 
Sesbania aculeta on physical properties of soil and on growth of wheat in ricewheat and maize-wheat cropping systems in a semiarid region of India. Arid Soil Res. Rehabil. 6, 135-143.

FAO, 1993. Food and agriculture Statistics Global Outlook. Food and Agril Organization of the United Nations,

Jat, D., Naik, R. K., Khandelwal, N. K., Patel, B. and Shrivastva, P. 2015. Land holding effect on energy inputs for soybean production in Malwa plateau of Madhya Pradesh. American International Journal of Research in Science Technology, Engineering and Mathematics, 9(3): 269-274.

Zoerab, G. C. and Popoff, J. 1967. Direct indication of tractor-wheel slip. Canadian Agricultural Engineering, 9: 91-108.

\section{How to cite this article:}

Jitendra Kumar, A.K. Dave and Shambhu Singh. 2021. Comparative Performance of Conservation Machinery System for Rice-Chickpea Cropping System in Vertisol of Chhattisgarh. Int.J.Curr.Microbiol.App.Sci. 10(01): 1902-1909. doi: https://doi.org/10.20546/ijcmas.2021.1001.222 